\begin{tabular}{lllllllll}
\hline $\mathrm{M}$ & $\mathrm{A}$ & $\mathrm{T}$ & $\mathrm{E}$ & $\mathrm{R}$ & $\mathrm{I}$ & $\mathrm{A}$ & $\mathrm{E}$ & $\mathrm{Y}$
\end{tabular}

\title{
UPOSAŻENIE PROFESORA ZWYCZAJNEGO POLSKIEJ PAŃSTWOWEJ SZKOŁY AKADEMICKIEJ OD 1 II 1934 DO 30 IX 1939 R.
}

\section{Wprowadzenie}

Niniejsza praca jest kontynuacją zagadnień już podnoszonych przez autora na łamach „Roczników Dziejów Społecznych i Gospodarczych”. W roczniku LXXI omówione zostały kwestie uposażeń profesorów zwyczajnych w polskim państwowym szkolnictwie akademickim od $1 \mathrm{X}$ 1923 r. do 31 I 1934 r., czyli w czasie obowiązywania tzw. systemu punktowego ${ }^{1}$. W tym miejscu przeanalizujemy tzw. kwotowy system uposażeń interesującej nas grupy nauczycieli akademickich, który był jego bezpośrednim następcą i obowiązywał do końca II Rzeczypospolitej. Dodajmy jednak gwoli ścisłości, że ustawa konstytuująca ten system uposażeń zachowała swa moc także po zakończeniu okupacji i została uchylona przez władze komunistyczne dopiero w 1949 r. Dokonamy także porównań najistotniejszych różnic między systemem kwotowym a jego poprzednikiem - systemem punktowym, by zobrazować kierunki ewolucji polityki państwa w odniesieniu do regulacji uposażeń.

Przypomnijmy, że w okresie międzywojennym obowiązywały cztery kolejne systemy ustalania wysokości uposażeń profesorów państwowych szkół akademickich. W pierwszym okresie, od 1 I $1919^{2}$ do 30 VI 1920 r., funkcjonował ułomny system kwotowy. Ułomny, ponieważ nie

${ }^{1}$ J. Jastrzębski, Uposażenie profesora zwyczajnego polskiej państwowej szkoty akademickiej w okresie od 1 X 1923 do 31 I 1934 r., RDSG 71, 2011, s. 157-182.

${ }^{2}$ Wówczas Państwo Polskie objęło wynagrodzeniami profesorów uczelni galicyjskich. Na Uniwersytecie Warszawskim i Politechnice Warszawskiej profesorowie pojawili się dopiero w trakcie 1919 r., zastępując tzw. wykładających. D. Zamojska, Akademicy $i$ urzędnicy. Kształtowanie ustroju państwowych szkót wyższych $w$ Polsce 1915-1920, Warszawa 2009, s. 21-63. 
był on systemem w pełnym tego słowa znaczeniu. Nie istniał bowiem jeden spójny akt normatywny, który określałby wszystkie podstawowe zasady wynagrodzeń. Poszczególne składniki uposażenia i ich wysokość były określane doraźnie, do czasu pojawienia się nowej, również tymczasowej regulacji ${ }^{3}$.

W drugim okresie, trwajacym od 1 VII 1920 do 30 IX 1923 r., obowiązywał system mnożnikowy. Miał on jednolita podstawę prawna, choć i ją trudno nazwać zupełna. Najogólniej mówiąc, obliczanie wysokości poszczególnych składników uposażenia w tym systemie opierało się na dwóch zmiennych: mnożnej i mnożniku, zależnych od różnych czynników określonych przepisami państwowymi (takimi jak wielkość rodziny, miejsce pracy, staż pracy itd.), niektóre składowe uposażenia obliczane były jednak jeszcze inaczej. ${ }^{4}$. Trzy główne powody zadecydowały o rezygnacji z systemu mnożnikowego.

Po pierwsze, był on bardzo skomplikowany, a spory w tym udział miała bałaganiarska działalność prawodawcy. Zmiany kosztów utrzymania, czyli po prostu inflacja, okazały się dla tego systemu zbyt trudnym sprawdzianem, zwłaszcza gdy przekształciła się w hiperinflację. Było po prostu zbyt wiele zmiennych, które należało mieć pod kontrola.

Po drugie, wprowadzenie nowego systemu, punktowego, pozostawało $\mathrm{w}$ związku z planowaną reformą walutową przygotowywana przez Władysława Grabskiego, która miała w założeniach doprowadzić również do większej stabilności cen. System punktowy miał tę niewątpliwą zaletę, że zachowywał przejrzystość i spójność zarówno w warunkach inflacyjnych, jak i deflacyjnych, a tym bardziej w rzadkim przypadku stabilizacji wartości siły nabywczej pieniądza. Przebudowa zasad

${ }^{3}$ Do ważniejszych aktów normatywnych w tym zakresie należały: Reskrypt Rady Regencyjnej z dnia 11 czerwca 1918 r. Tymczasowe przepisy stużbowe dla urzędników państwowych, Dz. U. 1918, nr 6, poz. 13; Rozporzadzenie Rady Ministrów z dnia 10 marca 1919 r. w przedmiocie tymczasowej regulacji płac profesorów, docentów prywatnych $i$ pomocniczych sit naukowych $w$ szkołach wyższych na terytorium $b$. zaboru austriackiego, Dz. U. 1919, nr 42, poz. 302; Rozporzadzenie Ministra Wyznań Religijnych i Oświecenia Publicznego z dnia 22 listopada 1920 r. w sprawie poborów profesorów, docentów i pomocniczych sił naukowych $w$ państwowych szkołach wyższych, „Monitor Polski” (dalej: M.P.) 1920, nr 46.

${ }^{4}$ Podstawą systemu była Ustawa z dnia 13 lipca 1920 r. o uposażeniu profesorów, innych wykładajacych i pomocników naukowych $w$ państwowych szkołach akademickich, Dz. U. 1920, nr 65, poz. 432. Ogłoszona 31 VII 1920 r. Weszła w życie z moca wsteczna 1 VII 1920 r. Nowelizowania raz: Ustawa $z$ dnia 31 marca 1922 r. o uposażeniu profesorów i pomocniczych sit naukowych w szkołach akademickich, Dz. U. 1922, $\mathrm{nr} 28$, poz. 226, skala jednak tej nowelizacji była tak duża, że nowy akt prawny niemal zastapił stary. Uchylona 1 X 1923 r. Ustawa z dnia 9 października 1923 r. o uposażeniu funkcjonariuszy państwowych i wojska, Dz. U. 1923, nr 116, poz. 924. 
wynagradzania funkcjonariuszy państwowych miała również pozytywnie wpłynąć na zarówno powodzenie przewalutowania z marki polskiej na złotego polskiego, jak i zduszenie presji inflacyjnej, w sposób niepodkopujący zaufania pracowników budżetowych do państwa polskiego, mocno nadwyrężonego dotychczasowa polityka płacowa.

Po trzecie, sytuacja materialna funkcjonariuszy państwowych od lata 1923 r., a zwłaszcza jesienia, stała się katastrofalna, dalsze lekceważenie ich potrzeb groziło paraliżem struktur państwowych. Konieczność zmuszała do przebudowy systemu w sposób radykalny i przywracający wysokość uposażenia do poziomu zapewniającego utrzymanie funkcjonariuszom oraz członkom ich rodzin. Nie należy w tym przypadku lekceważyć czynnika psychologicznego - nowa ustawa uposażeniowa symbolizowała nowy ład, dając nadzieję na pozytywne zmiany.

Wprowadzenie systemu punktowego zapoczątkowało trzeci okres kształtowania płac profesorskich, trwający od 1 X 1923 do 31 I 1934 r. Obliczanie uposażenia opierało się na ustalonej stałej mnożnej, której wartość wyrażana była w ilości tzw. punktów uposażeniowych. Ich liczba dla każdego składnika uposażenia zależna była od różnych czynników określonych przepisami państwowymi, a wartość była zmienna w czasie i miała na nią wpływ wysokość inflacji. Podstawa tego systemu była Ustawa z dnia 9 października 1923 r. o uposażeniu funkcjonariuszy państwowych $i$ wojska ${ }^{5}$. System punktowy obowiazywał zdecydowanie najdłużej spośród wszystkich tego rodzaju systemów okresu międzywojennego, bo aż 10 lat i 4 miesiące. Był też logicznie pomyślany i całkiem dobrze sprawdzał się w warunkach długotrwałej inflacji. Jednak w warunkach dużej stabilności pieniądza, cechującej lata 30., skomplikowanie systemu punktowego było i tak nadmierne. W tym należy doszukiwać się podstawowej przyczyny rezygnacji z systemu punktowego i zastapienia bardzo prostym systemem kwotowym.

W czwartym i zarazem ostatnim okresie, trwającym od 1 II 1934 r. do końca II Rzeczypospolitej, obowiązywał ponownie system kwotowy, tym razem pełny. Poszczególne składniki uposażenia ustalano bezpośrednio w złotych, bez konieczności dokonywania jakichkolwiek przeliczeń.

${ }^{5}$ Ustawa z dnia 9 października 1923 r. o uposażeniu funkcjonariuszy państwowych $i$ wojska, Dz. U. 1923, nr 116, poz. 924. Ogłoszona 15 XI 1923 r. Weszła w życie z moca wsteczną 1 X 1923 r. Sprostowana Zarzqdzeniem Prezydenta Rzeczypospolitej z dnia 14 stycznia 1924 r. w przedmiocie sprostowania błędu w ustawie z dnia 9 października 1923 r. o uposażeniu funkcjonariuszy państwowych i wojska, Dz. U. 1924, nr 3, poz. 15. Nowelizowana 17 razy, w tym $12 \mathrm{w}$ zakresie dotyczącym szkolnictwa akademickiego. Uchylona 1 II 1934 r. Rozporzqdzeniem Prezydenta Rzeczypospolitej z dnia 28 października 1933 r. o uposażeniu funkcjonariuszy państwowych, Dz. U. 1933, nr 86, poz. 663. 
Podstawą prawną systemu było Rozporzqdzenie Prezydenta Rzeczypospolitej z dnia 28 października 1933 r. o uposażeniu funkcjonariuszy państwowych ${ }^{6}$. Powinno ono być jednak rozpatrywane łącznie z głównym aktem wykonawczym, czyli Rozporzqdzeniem Rady Ministrów z dnia 19 grudnia 1933 r. o zasadach zaszeregowania funkcjonariuszy państwowych do grup uposażenia $i$ automatycznego przechodzenia nauczycieli do wyższych grup uposażenia, o dodatkach lokalnych, funkcyjnych $i$ stużbowych oraz o umundurowaniu niższych funkcjonariuszy państwowych ${ }^{7}$. Właśnie temu systemowi poświęcony jest niniejszy artykuł.

\section{System kwotowy}

Uposażenie profesorów zwyczajnych miało w systemie kwotowym wspólną podstawę prawną z uposażeniem innych cywilnych funkcjonariuszy państwowych. Było to nieco odmienne rozwiązanie od przyjętego w systemie punktowym, gdy analogiczny akt prawny obejmował także wojskowych. Inaczej było także w starszym systemie mnożnikowym, w którym nauczyciele akademiccy mieli całkowicie odrębną regulację swych uposażeń ${ }^{\text {. }}$

Profesor zwyczajny został zaliczony do IV grupy uposażeniowej. Było to rozwiązanie identyczne $\mathrm{z}$ obowiązującym poprzednio, $\mathrm{z}$ tym zastrzeżeniem, że w nowym systemie nie było żadnego podziału w ramach grupy uposażeniowej na szczeble, różniące się wysokością płacy zasadniczej. Wszystkim profesorom zwyczajnym przysługiwała stawka jednolita,

${ }^{6}$ Rozporzqdzenie Prezydenta Rzeczypospolitej z dnia 28 października 1933 r. o uposażeniu funkcjonariuszy państwowych, Dz. U. 1933, nr 86, poz. 663. Ogłoszone $30 \mathrm{X}$ 1933 r. Weszło w życie 1 II 1934 r. Nowelizowane 7 razy, w tym dwukrotnie w okresie międzywojennym: Rozporzadzeniem Prezydenta Rzeczypospolitej z dnia 28 października 1933 r. o uposażeniu oficerów i szeregowych Policji Państwowej i Straży Granicznej, Dz. U. 1933, nr 86, poz. 666, oraz Dekretem Prezydenta Rzeczypospolitej z dnia 29 września 1936 r. w sprawie zmiany rozporzqdzenia Prezydenta Rzeczypospolitej z dnia 28 października 1933 r. o uposażeniu funkcjonariuszy państwowych, Dz. U. 1936, nr 75, poz. 531. Uchylone 1 I 1949 r. Ustawq z dnia 4 lutego 1949 r. o uposażeniu pracowników państwowych $i$ samorzadowych oraz przewodniczqcych organów wykonawczych gmin wiejskich i miejskich, Dz. U. 1949, nr 7, poz. 39.

${ }^{7}$ Rozporzqdzenie Rady Ministrów z dnia 19 grudnia 1933 r. o zasadach zaszeregowania funkcjonariuszy państwowych do grup uposażenia $i$ automatycznego przechodzenia nauczycieli do wyższych grup uposażenia, o dodatkach lokalnych, funkcyjnych $i$ stużbowych oraz o umundurowaniu niższych funkcjonariuszy państwowych, Dz. U. 1933, nr 102, poz. 781. Ogłoszone 30 XII 1933 r. Weszło w życie z dniem 1 II 1934 r.

${ }^{8}$ Dz. U. 1920, nr 65, poz. 432; Dz. U. 1923, nr 116, poz. 924; Dz. U. 1933, nr 86, poz. 663. 
przewidziana dla owej IV grupy uposażeniowej. W systemie kwotowym nie trzeba było również dokonywać żadnych przeliczeń wartości punktów czy mnożnych, gdyż każdy składnik uposażenia był wyrażony bezpośrednio w złotych polskich ${ }^{9}$.

\section{Klasyfikacja uposażeń}

W niniejszej pracy interesuje nas jedynie wynagrodzenie ściśle związane z pełnieniem funkcji profesora zwyczajnego, dlatego pomijamy $\mathrm{w}$ niej uposażenia dodatkowe, jak przykładowo z tytułu zastępstw lub prowadzenia zajęć zleconych. Wspomnijmy tylko, że wysokość wynagrodzeń dodatkowych i zasady ich otrzymywania ustalała Rada Ministrów $^{10}$. Uposażenie profesora zwyczajnego możemy podzielić na dwie części: uposażenie podstawowe i uposażenie uzupełniające.

Uposażenie podstawowe było to uposażenie przysługujące każdemu profesorowi zwyczajnemu w całym okresie obowiązywania systemu kwotowego. Uposażenie uzupełniające to zaś uposażenie przysługujące tylko tym, którzy spełniali określone prawem kryteria, czyli przede wszystkim mieszkali w określonym miejscu lub pełnili dodatkowe funkcje. Uposażenie podstawowe profesora zwyczajnego było jednoskładnikowe i sprowadzało się do płacy zasadniczej. Była to istotna różnica w stosunku do poprzedniego systemu uposażeń, który był trójskładnikowy i obejmował: płacę zasadnicza, dodatek regulacyjny oraz dodatek naukowy.

Z obu powyższych dodatków zrezygnowano. Zostały ustanowione na czas hiperinflacji, by chronić siłę nabywczą płacy zasadniczej i ograniczyć ujemny wpływ wzrostu cen na wydatki profesorskie związane z prowadzona działalnością badawczą i dydaktyczna (np. zakup ksiażek, materiałów piśmienniczych itd.). Gdy presja inflacyjna została stłumiona, ich nadzwyczajna rola faktycznie przestała być zauważalna i zrównała się z płaca zasadnicza. Dlatego w nowym systemie kwotowym zrezygnowano z nich, co wobec znacznego podwyższenia profesorskiej płacy zasadniczej nie miało żadnego ujemnego wpływu na ich dochody, do czego jeszcze wrócimy w dalszym wywodzie.

Uposażenie uzupełniajace profesora zwyczajnego w systemie kwotowym mogły tworzyć maksymalnie 2 składniki ${ }^{11}$ :

${ }^{9}$ Dz. U. 1923, nr 116, poz. 924; Dz. U. 1933, nr 86, poz. 663; Dz. U. 1933, nr 102, poz. 781 .

${ }^{10}$ Dz. U. 1933, nr 86, poz. 663.

${ }^{11}$ Tylko teoretycznie profesorom zwyczajnym mógłby przysługiwać jeszcze dodatek wyrównawczy, zwany wówczas zasiłkiem wyrównawczym. Przysługiwał on tym funk- 
1) dodatek lokalny,

2) dodatek funkcyjny.

Istniała co prawda potencjalna możliwość uzyskania także dodatku rodzinnego, lecz ze względu na wysokie uposażenie podstawowe profesor zwyczajny nie miał na to większych szans. Dodatek ten mógł być przyznawany funkcjonariuszom państwowym utrzymującym liczniejsza rodzinę, uzyskiwali go jednak przede wszystkim ci mniej zarabiający. Nie był zatem prostym zastępnikiem dodatku ekonomicznego znanego z punktowego systemu uposażen, który w tamtym systemie przysługiwał wszystkim funkcjonariuszom państwowym niezależnie od ich statusu uposażeniowego, podczas gdy dodatek rodzinny w systemie kwotowym był przyznawany indywidualnie. Biorąc pod uwagę to, co wyżej powiedzieliśmy, odstapimy od uwzględnienia tego dodatku w naszych rozważaniach.

\section{Wypłata uposażeń}

Profesor zwyczajny mógł otrzymywać od Skarbu Państwa tylko jedno stałe uposażenie służbowe jako wynagrodzenie za ogół czynności, których obowiązek wykonywania wynikał z zajmowania tego stanowiska. Jeżeli profesor otrzymał mieszkanie w naturze, jego wartość potrącano z uposażenia podstawowego. Uposażenie profesora zwyczajnego wolne było od podatku dochodowego i opłat emerytalnych ${ }^{12}$.

Uposażenie wypłacane było miesięcznie, z góry, w pierwszym dniu każdego miesiąca kalendarzowego, a jeżeli dzień ten był ustawowo wolny od pracy (niedziela lub święto), w ostatnim dniu poprzedniego

cjonariuszom państwowym, których uposażenie według nowych zasad (płaca zasadnicza plus dodatki: lokalny, funkcyjny i służbowy) byłoby mniejsze od pobieranego w styczniu 1934 r. o więcej niż 7\%. Pokrywał on różnicę między wynagrodzeniem obliczonym zgodnie ze standardowymi wytycznymi systemu kwotowego a dotychczasowym wynagrodzeniem pomniejszonym o owe 7\%. Przy czym nie przysługiwał on, jeśli jego wysokość byłaby niższa niż 10 zł. Dodatek wypłacano w zaokragleniu do 5 zł. Jak wynika z naszych przedstawianych dalej obliczeń, w zasadzie nie było możliwości zaistnienia sytuacji, która obligowałaby państwo do takiej wypłaty profesorowi zwyczajnemu. Wyjątek mógłby dotyczyć jedynie profesora otrzymującego szczególnie wysoki dodatek osobisty, lecz jeżeli w ogóle w styczniu 1934 r. komukolwiek on przysługiwał, to już niezwykle mało prawdopodobne, by jego wartość przybrała aż tak znaczną wysokość. Dodatkowo zasiłek wyrównawczy nie przysługiwał albo podlegał stosownemu zmniejszeniu, jeżeli zainteresowany uzyskałby prawo do dodatku funkcyjnego, którego poprzednio nie otrzymywał, względnie pobierał go w niższej wysokości. Dz. U. 1933, nr 102, poz. 781.

${ }^{12}$ Dz. U. 1933, nr 86, poz. 663. 
miesiąca ${ }^{13}$. Profesor zwyczajny, który wstępował do służby po raz pierwszy albo ponownie po przerwie, nabywał prawo do uposażenia od dnia rzeczywistego objęcia stanowiska. Jeżeli objął stanowisko w pierwszym dniu miesiąca kalendarzowego, przysługiwało mu pełne uposażenie miesięczne. Jeżeli jednak objęcie obowiązków nastapiło w innym dniu miesiąca kalendarzowego, przysługiwało mu za ten miesiac uposażenie proporcjonalnie zmniejszone. Za każdy dzień służby przysługiwała 1/30 uposażenia za miesiąc pełny (stawka dniówkowa). Nie była istotna rzeczywista długość danego miesiąca kalendarzowego, za każdy jego dzień (także w miesiącach 28-, 29- i 31-dniowych), przysługiwała stawka dniówkowa jak za miesiąc 30-dniowy. Tak obliczona stawka dniówkowa była następnie mnożona przez ilość dni służby w danym miesiącu, wynik iloczynu stanowił należne uposażenie $\mathrm{w}$ pierwszym miesiącu kalendarzowym służby ${ }^{14}$. Była to istotna zmiana względem stanu dotychczasowego, w którym profesor nabywał prawo do uposażenia albo od pierwszego dnia miesiąca - jeżeli rzeczywiste objęcie stanowiska nastapiło pomiędzy 1 a 15 dniem danego miesiąca kalendarzowego, albo od 16 dnia miesiąca - jeżeli rzeczywiste objęcie stanowiska nastapiło pomiędzy 16 a ostatnim dniem danego miesiąca kalendarzowego. Modyfikacja czyniła zatem sytuację bardziej sprawiedliwa, dotąd bowiem osoba rozpoczynająca pracę 15 dnia miesiąca otrzymywała aż o połowę większe wynagrodzenie za ów miesiąc niż ta, która uczyniła to $\mathrm{w}$ dniu następnym ${ }^{15}$.

Profesor, który pełnił służbę państwową już wcześniej, nabywał prawo do uposażenia z pierwszym dniem najbliższego miesiąca kalendarzowego, po dniu mianowania na stanowisko profesora zwyczajnego lub po powstaniu warunków uzasadniajacych zmianę w wymiarze jego uposażenia. Jeżeli jednak przyczyna powodująca zmianę w prawie do uposażenia zbiegła się z dniem jego wypłaty, to prawo do uposażenia nabywało się z tym dniem. Przy czym w razie zmiany miejsca służbowego, pociagającej za sobą zmianę wysokości uposażenia, przysługiwało profesorowi zwyczajnemu prawo do uposażenia, jakie odpowiadało nowemu miejscu służbowemu od pierwszego dnia miesiąca kalendarzowego

${ }^{13}$ Rozporzqdzenie Rady Ministrów z dnia 20 stycznia 1934 r. w sprawie terminu płatności uposażenia, Dz. U. 1934, nr 8, poz. 63. Ogłoszone 30 I 1934 r. Weszło w życie z dniem 1 II 1934 r. Nie było nowelizowane. Uchylone 1 I 1949 r. Ustawa z dnia 4 lutego 1949 r. o uposażeniu pracowników państwowych $i$ samorzqdowych oraz przewodniczacych organów wykonawczych gmin wiejskich i miejskich, Dz. U. 1949, nr 7, poz. 39.

${ }^{14}$ Dz. U. 1933, nr 86, poz. 663.

${ }^{15}$ Dz. U. 1923, nr 116, poz. 924. 
następującego po zwolnieniu go od poprzednich obowiązków służbowych $^{16}$. Jako moment, od którego liczyło się w tym przypadku prawo do zmiany uposażenia, traktowano datę doręczenia decyzji stanowiacej podstawę prawna do owej zmiany, o ile w samym dokumencie nie ustalono innego terminu. Wynikało to z ogólnej zasady prawnej, że akt administracyjny rodził skutki z chwila podania go do wiadomości zainteresowanej strony ${ }^{17}$.

Prawo do uposażenia służbowego gasło $\mathrm{z}$ ostatnim dniem miesiąca kalendarzowego, w którym stosunek ten ustał, i z tym dniem wypłatę uposażenia wstrzymywano. Jedynie w przypadku, gdyby profesor zwyczajny samowolnie opuścił służbę, co mamy prawo uznać za możliwość czysto teoretyczna, obowiąany był zwrócić część uposażenia za okres nieprzesłużony. Zwrot nienależnie pobranego uposażenia obliczano według zasad analogicznych jak przy nabyciu prawa do uposażenia w służbie państwowej po raz pierwszy. Za każdy dzień nieprzesłużony zwrotowi podlegała 1/30 uposażenia za miesiąc pełny; jeżeli samowolne opuszczenie służby nastapiłoby w pierwszym dniu miesiąca kalendarzowego, zwrotowi podlegało całe wypłacone uposażenie miesięczne. Nie była istotna rzeczywista długość danego miesiąca kalendarzowego, za każdy jego dzień (także w miesiącach 28-, 29- i 31-dniowych) naliczano stawkę dniówkowa. Tak obliczona stawka dniówkowa była następnie mnożona przez ilość dni nieprzesłużonych w danym miesiącu, wynik iloczynu stanowił należny Skarbowi Państwa zwrot uposażenia za miesiąc, w którym samowolne opuszczenie służby miałoby miejsce.

Profesorowi, w przypadku zasługującym na uwzględnienie, mogła być udzielona bezprocentowa zaliczka na uposażenie. Warunki przyznawania takiej zaliczki i jej wysokość określał Prezes Rady Ministrów w porozumieniu z Ministrem Skarbu.

Roszczenia profesorów względem Skarbu Państwa wynikające z tytułu uposażenia przedawniały się z upływem lat trzech, licząc od dnia jego powstania. Każda czynność podjęta przez zainteresowanego $\mathrm{w}$ celu dochodzenia wierzytelności przerywała bieg przedawnienia ${ }^{18}$.

${ }^{16}$ Dz. U. 1933, nr 86, poz. 663.

${ }^{17}$ Okólnik Nr 21 z dnia 18 marca 1937 r. (BP-3434/37) w sprawie nabycia $i$ utraty prawa do uposażenia - „Dziennik Urzędowy Ministerstwa Wyznań Religijnych i Oświecenia Publicznego" (dalej: Dz. Urz. Min.W.R.O.P.) 1937, nr 4, poz. 94.

${ }^{18}$ Dz. U. 1933, nr 86, poz. 663. 


\section{Uposażenie podstawowe - płaca zasadnicza}

Wyznaczanie wysokości płacy zasadniczej (zwanej również uposażeniem zasadniczym) profesora zwyczajnego zostało w systemie kwotowym maksymalnie uproszczone. Dotąd w systemie punktowym IV grupa uposażenia, do której zaliczał się profesor zwyczajny, dzieliła się na sześć szczebli. Każdemu szczeblowi przysługiwała inna kwota płacy zasadniczej, a przypisanie do konkretnego szczebla zależało przede wszystkim od czasu pełnienia służby państwowej ${ }^{19}$. Od 1 II 1934 r. płaca zasadnicza dla każdego profesora zwyczajnego została wyznaczona na poziomie 1000 złotych miesięcznie ${ }^{20}$, a jej wysokość nie ulegała zmianom do końca II Rzeczypospolitej. Oznaczało to likwidację szczebli uposażenia i zrównanie uposażenia podstawowego wszystkich profesorów zwyczajnych, niezależnie od wysługi lat. Żebyśmy mogli jednak miarodajnie porównać rzeczywistą różnicę w wysokości płac profesorskich, musimy sprowadzić poszczególne składniki uposażeń w obu okresach do wspólnego mianownika. Będzie nim kategoria uposażenia podstawowego, które w nowym systemie wynagrodzeń było tożsame z pojęciem płacy zasadniczej. W starym systemie na ten rodzaj uposażenia profesora zwyczajnego obok płacy zasadniczej składały się także dodatek regulacyjny i dodatek naukowy. Dopiero takie porównanie możemy uznać za miarodajne, a przedstawia je tabela 1 .

Tabela 1. Porównanie wysokości uposażenia podstawowego profesorów zwyczajnych ze stycznia i z lutego $1934 \mathrm{r}$.

\begin{tabular}{l|c|c}
\hline \multicolumn{1}{c|}{ Miesiąc } & Szczeble uposażenia & Kwota (zł) \\
\hline \multirow{4}{*}{ styczeń 1934 r. (system punktowy) } & $\mathrm{a}$ & 692,30 \\
\cline { 2 - 3 } & $\mathrm{b}$ & 735,30 \\
\cline { 2 - 3 } & $\mathrm{c}$ & 778,30 \\
\cline { 2 - 3 } & $\mathrm{d}$ & 821,30 \\
\cline { 2 - 3 } & $\mathrm{e}$ & 864,30 \\
\cline { 2 - 3 } & $\mathrm{f}$ & 885,80 \\
\hline luty 1934 r. (system kwotowy) & - & 1000,00 \\
\hline
\end{tabular}

Źródło: Opracowanie i obliczenia własne na podstawie: Dz. U. 1923, nr 116, poz. 924; Dz. U. 1925, nr 117, poz. 839; Dz. U. 1925, nr 129, poz. 918; Dz. U. 1933, nr 86, poz. 663.

Uwaga: Na uposażenie podstawowe w styczniu 1934 r. składały się: płaca zasadnicza, dodatek regulacyjny i dodatek naukowy. Na uposażenie podstawowe w lutym 1934 r. składała się tylko płaca zasadnicza, gdyż nie istniał żaden inny składnik uposażeniowy, który przysługiwałby bez wyjątku wszystkim profesorom zwyczajnym.

${ }^{19}$ Dz. U. 1933, nr 86, poz. 663; Dz. U. 1923, nr 116, poz. 924.

${ }^{20}$ Dz. U. 1933, nr 102, poz. 781. 
Nowa stawka tego wynagrodzenia została wyznaczona na poziomie wyższym, niż wynosiło ono na wszystkich szczeblach w systemie punktowym, zatem oznaczało to podwyżkę dla wszystkich zainteresowanych, tyle że nieproporcjonalną ${ }^{21}$. Najwięcej zyskiwali profesorowie dotąd najmniej zarabiający, najmniejszymi beneficjantami zmian byli profesorowie dotychczas pobierajacy najznaczniejszą kwotę uposażenia podstawowego.

Aby jednak nie popadać w nadmierny hurraoptymizm co do skali zmian płacowych na korzyść profesorów zwyczajnych, należy w tym miejscu zwrócić uwagę na niezwykle istotną okoliczność. W systemie punktowym funkcjonowała instytucja dodatku ekonomicznego. Jego wysokość uzależniona była od liczebności profesorskiej rodziny, przy czym przyjmowano tu stałą stawkę na każdego członka rodziny. Wysokość dodatku ekonomicznego nie pozostawała w związku ani z zaszeregowaniem do określonej grupy i szczebla uposażenia, ani z przysługująca kwota innych składowych uposażenia. Wszyscy funkcjonariusze państwowi otrzymywali ów dodatek według identycznej stawki, zależny jedynie od liczebności rodziny. Dodatek ekonomiczny wypłacano co miesiąc wraz z uposażeniem podstawowym ${ }^{22}$. Miesięczna stawka dodatku ekonomicznego na jednego członka rodziny wynosiła w styczniu $1934 \mathrm{r}$. $18,92 \mathrm{zł}^{23}$. Wysokość dodatku ekonomicznego obliczano zatem mnożąc liczbę członków rodziny, z wyłączeniem samego profesora, przez ową stawkę. Uwzględniano maksymalnie 5 takich członków, posiadanie jeszcze większej rodziny już nie wiązało się z kolejnymi gratyfikacjami finansowymi. Dodatku ekonomicznego nie zaliczymy do uposażenia podstawowego, gdyż nie przysługiwał on profesorom samotnym ${ }^{24}$. Zauważmy przy tym jednak, że obowiązujący wówczas system wartości kulturowych sprawiał, że rodziny (żonę, dzieci) miała przytłaczająca większość kadry profesorskiej (o czym zreszta w pewnym sensie przesądzała także stosunkowo wysoka średnia wieku przeciętnego profesora zwyczajnego). Tymczasem w systemie kwotowym zniesiono instytucję dodatku ekonomicznego ${ }^{25}$. Wysokość płacy zasadniczej musiała wyrównać ów brak. Dla nielicznych profesorów samotnych nie miało to

${ }^{21}$ Dz. U. 1923, nr 116, poz. 924; Rozporzadzenie Rady Ministrów z dnia 17 listopada 1925 r. o ustaleniu na miesiac grudzień 1925 r. mnożnej dla określenia uposażenia funkcjonariuszy państwowych $i$ wojska, Dz. U. 1925, nr 117, poz. 839; Ustawa $z$ dnia 22 grudnia 1925 r. o środkach zapewnienia równowagi budżetowej, Dz. U. 1925, nr 129, poz. 918; Dz. U. 1933, nr 86, poz. 663.

${ }^{22}$ Dz. U. 1923, nr 116, poz. 924.

${ }^{23}$ Dz. U. 1923, nr 116, poz. 924; Dz. U. 1925, nr 117, poz. 839; Dz. U. 1925, nr 129, poz. 918.

${ }^{24}$ Dz. U. 1923, nr 116, poz. 924.

${ }^{25}$ Dz. U. 1933, nr 86, poz. 663. 
znaczenia, lecz dla profesorów z rodzinami niwelowało to większą lub mniejszą część korzyści z podwyżki uposażenia podstawowego. Porównanie wysokości uposażenia podstawowego profesorów zwyczajnych $\mathrm{w}$ obu systemach z uwzględnieniem dodatku ekonomicznego przedstawia tabela 2 .

Tabela 2. Porównanie wysokości uposażenia podstawowego profesorów zwyczajnych ze stycznia i z lutego 1934 r. z uwzględnieniem dodatku ekonomicznego

\begin{tabular}{l|c|c|c|c|c|c|c}
\hline \multirow{2}{*}{ Miesiąc } & \multirow{2}{*}{$\begin{array}{c}\text { Szczeble } \\
\text { uposażenia }\end{array}$} & \multicolumn{6}{|c}{ Kwota (zł) zależna od ilości członków rodziny } \\
\cline { 2 - 8 } & $\mathbf{0}$ & $\mathbf{1}$ & $\mathbf{2}$ & $\mathbf{3}$ & $\mathbf{4}$ & $\mathbf{5}$ \\
\hline & $\mathrm{a}$ & 692,30 & 711,22 & 730,14 & 749,06 & 767,98 & 786,90 \\
\cline { 2 - 8 } & $\mathrm{b}$ & 735,30 & 754,22 & 773,14 & 792,06 & 810,98 & 829,90 \\
\cline { 2 - 8 } & $\mathrm{c}$ & 778,30 & 797,22 & 816,14 & 835,06 & 853,98 & 872,90 \\
\cline { 2 - 8 } $\begin{array}{l}\text { styczeń 1934 r. } \\
\text { (system punktowy) }\end{array}$ & $\mathrm{d}$ & 821,30 & 840,22 & 859,14 & 878,06 & 896,98 & 915,90 \\
\cline { 2 - 8 } & $\mathrm{e}$ & 864,30 & 883,22 & 902,14 & 921,06 & 939,98 & 958,90 \\
\cline { 2 - 8 } & $\mathrm{f}$ & 885,80 & 904,72 & 923,64 & 942,56 & 961,48 & 980,40 \\
\hline $\begin{array}{l}\text { luty 1934 r. } \\
\text { (system kwotowy) }\end{array}$ & - & \multicolumn{7}{|c|}{1000} \\
\hline
\end{tabular}

Źródło: Opracowanie i obliczenia własne na podstawie: Dz. U. 1923, nr 116, poz. 924; Dz. U. 1925, nr 117, poz. 839; Dz. U. 1925, nr 129, poz. 918; Dz. U. 1933, nr 86, poz. 663.

Jak widać z przedstawionych danych, jeśli ograniczymy nasze rozważania do uposażenia podstawowego z uwzględnieniem dodatku ekonomicznego, to $\mathrm{w}$ rzeczywistości najwięcej na zmianach skorzystali samotni profesorowie zwyczajni poprzednio zaszeregowani do najniższego szczebla uposażeniowego. W starym systemie punktowym pobierali oni najmniejsze tak rozumiane uposażenie. Najmniej zyskali profesorowie zwyczajni mający pięcioosobową bądź liczniejszą rodzinę, poprzednio zaszeregowani do najwyższego szczebla uposażeniowego. W starym systemie punktowym pobierali oni największe tak rozumiane uposażenie. W systemie kwotowym jednym i drugim przysługiwało ono w identycznej wysokości (mówiąc to pamiętajmy jednak, że samotni profesorowie zwyczajni należeli do wyjątków).

Znacznie trudniej oszacować realną skalę korzyści, jakie z owej nominalnej podwyżki odnieśli zainteresowani. Ostatnia zmiana wysokości płacy zasadniczej, dodatku regulacyjnego, dodatku naukowego i dodatku ekonomicznego nastapiła z dniem 1 IV 1926 r. Odtąd pozostawała na niezmienionym poziomie do 31 I $1934 \mathrm{r} .{ }^{26}$ Było to w największej

${ }^{26}$ J. Dybiec, Uniwersytet Jagielloński 1918-1939, Kraków 2000, s. 126-142; J. Jastrzębski, dz. cyt., s. 157-182. 
mierze spowodowane względną stabilnością siły nabywczej złotówki. Względną - ponieważ oczywiście ceny nigdy nie stoją długo w miejscu. $\mathrm{W}$ istocie powyższy czas można $\mathrm{w}$ przybliżeniu podzielić na dwie części. W latach 1926-1929 - dobrej koniunktury w polskiej gospodarce - ceny wahały się w górę i w dół, lecz ogólną tendencją był niewielki wzrost inflacji, a zatem i pewien spadek siły nabywczej uposażenia profesorskiego. Natomiast w latach 1930-1934 - kryzysu w polskiej gospodarce - ceny głównie spadały, zatem ogólną tendencją była deflacja, a więc wzrost siły nabywczej uposażenia profesorskiego. Przy czym wszystko wskazuje na to, że ów drugi okres z nawiazką zniwelował wyniki okresu pierwszego. Ze względu na ograniczenia ówczesnej statystyki nie dysponujemy danymi, które mogłyby precyzyjnie wskazać ostateczny rezultat, skutek jednak musiał być dla statusu finansowego profesora pozytywny, wzmacniając efekt nominalnej podwyżki jego uposażenia podstawowego ${ }^{27}$.

\section{Dodatek lokalny}

Rada Ministrów mogła przyznać profesorowi dodatek do płacy zasadniczej uzasadniony warunkami lokalnymi w kraju ${ }^{28}$. W praktyce profesorów zwyczajnych dotyczył tylko dodatek lokalny, który przysługiwał funkcjonariuszom państwowym pełniącym służbę w Warszawie. Dla pozostałych miast akademickich takiego dodatku nie przewidziano. Dodatek lokalny przysługujacy profesorowi zwyczajnemu pełniącemu służbę w Warszawie wynosił 150 zł i kwota ta pozostała niezmieniona do końca II Rzeczypospolitej ${ }^{29}$.

Można wskazać dwa zasadnicze powody płacowego uprzywilejowania Warszawy względem Krakowa, Lwowa, Poznania i Wilna. Oba wynikały pośrednio z jej stołecznego charakteru. Największe miasto w Polsce było w sposób naturalny „miastem drogim”, w którym koszty utrzymania były wyższe niż w pozostałych regionach kraju ${ }^{30}$. Był to główny powód przyznania dodatku lokalnego funkcjonariuszom

${ }^{27}$ Historia Polski w liczbach, t. 2: Gospodarka, Warszawa 2006, s. 345-352; W. Morawski, Od marki do złotego. Historia finansów Drugiej Rzeczypospolitej, Warszawa 2008, s. 121-186; Z. Landau, J. Tomaszewski, Zarys historii gospodarczej Polski 1918-1939, Warszawa 1999, s. 150-247; J. Skodlarski, Zarys historii gospodarczej Polski, Warszawa 2000, s. 253-286.

${ }^{28}$ Dz. U. 1933, nr 86, poz. 663.

${ }^{29}$ Dz. U. 1933, nr 102, poz. 781.

${ }^{30}$ Historia Polski w liczbach, t. 2, s. 352. 
państwowym tu zatrudnionym, w tym profesorom. Poza tym Warszawa stanowiła wizytówkę Rzeczypospolitej Polskiej, gromadząc znaczna liczbę przyjezdnych z zagranicy. Tu przebywali przedstawiciele dyplomatyczni innych państw, tu odbywała się większość najważniejszych uroczystości i tu organizowano najwięcej różnego rodzaju konferencji i spotkań. Wysoki status i prestiż społeczny profesora akademickiego wymagał aktywniejszego uczestnictwa w życiu stolicy, niż to było wymagane w politycznie mniej znaczących ośrodkach. Oczekiwano od profesora również godnego reprezentowania kraju. Choć zatem wprost nigdzie tego $\mathrm{w}$ przepisach prawnych nie wyartykułowano, musiało to w jakieś mierze wpłynąć na ustanowienie interesującego nas dodatku dla stolicy, który, przypomnijmy, należny był także innym warszawskim funkcjonariuszom państwowym.

\section{Dodatki funkcyjne}

Dodatek funkcyjny przysługiwał profesorowi zwyczajnemu jedynie wtedy, gdy przepisy państwowe przewidywały takowy dla określonej funkcji w szkole akademickiej. A podkreślmy, że było wiele funkcji, których pełnienie nie wiązało się z żadną gratyfikacją finansową (np. prodziekan, członek Zebrania Ogólnego Profesorów, członek Rady Profesorów itp. $)^{31}$.

Dodatek funkcyjny $\mathrm{w}$ odniesieniu do stanowisk w szkolnictwie akademickim określany był różnymi nazwami w okresie II Rzeczypospolitej. Od 1 VII 1920 do 31 XII 1921 r. przepisy państwowe mówiły o wynagrodzeniu za czynności dodatkowe ${ }^{32}$, od 1 I 1922 r. o dodatku funkcyjnym ${ }^{33}$, zaś od 1 II 1934 r. - o dodatku służbowym ${ }^{34}$. Aby zachować spójność, będziemy posługiwać się pojęciem dodatku

${ }^{31}$ J. Jastrzębski, Prawo akademickie II Rzeczypospolitej. Źródła i wskazówki, Kraków 2010; tenże, Instytucja Zebrania Ogólnego Profesorów w państwowych szkołach akademickich II Rzeczypospolitej, „Zeszyty Naukowe Uniwersytetu Jagiellońskiego. Prace Historyczne” 2010, z. 137, s. 123-135; tenże, Dwie instytucje Rady Profesorów w państwowym szkolnictwie akademickim II Rzeczypospolitej, „Przegląd Historyczno-Oświatowy” 2011, nr 2-4 (213-214), s. 60-72; tenże, Instytucja Senatu w państwowym szkolnictwie akademickim II Rzeczypospolitej, „Wschodni Rocznik Humanistyczny" 4, 2009, s. 307-323;

${ }^{32}$ Dz. U. 1920, nr 65, poz. 432.

${ }^{33}$ Rozporzqdzenie Rady Ministrów $z$ dnia 14 sierpnia 1922 r. o wykonaniu ustawy $z$ dnia 31 marca 1922 r. o uposażeniu profesorów i pomocniczych sit naukowych w szkołach akademickich, Dz. U. 1922, nr 74, poz. 669.

${ }^{34}$ Dz. U. 1933, nr 86, poz. 663. 
funkcyjnego, który to termin w okresie międzywojennym obowiązywał najdłużej ${ }^{35}$.

Dodatek funkcyjny przysługiwał jedynie za okres faktycznego pełnienia obowiązków związanych z danym urzędem. Nie był zatem wypłacany osobom: pozostajacym w stanie nieczynnym, będącym na urlopach bezpłatnych, zawieszonym $\mathrm{w}$ pełnieniu służby, a także $\mathrm{w}$ przypadku niewypełniania $\mathrm{z}$ jakichkolwiek innych powodów obowiązków wynikających z funkcji, z którą odnośny dodatek był związany. Można było pobierać tylko jeden $\mathrm{z}$ interesujaccych nas tutaj dodatków funkcyjnych. W razie zbiegu tytułów do dwóch lub więcej z nich, uprawnionemu służyło prawo wyboru.

Profesorom zwyczajnym mógł przysługiwać jeden z następujących rodzajów dodatku funkcyjnego: dodatek rektorski, dodatek prorektorski, dodatek dziekański, dodatek za kierownictwo oddziału, dodatek za kierownictwo studium z własnym statutem, dodatek za kierownictwo zakładu. Ustalona na dzień 1 II 1934 r. wysokość dodatków funkcyjnych nie ulegała zmianie do końca II Rzeczypospolitej ${ }^{36}$. Dodajmy w tym miejscu, że w stosunku do stanu ze stycznia 1934 r. wysokość dodatków: rektorskiego, prorektorskiego, dziekańskiego oraz za kierowanie oddziałem i studium nie zmieniła się w nowym systemie uposażeń $^{37}$. Przywrócono natomiast dodatki za kierownictwo zakładem naukowym, do którego wypłaty w okresie od 1 IX 1933 do 31 I 1934 r. nie było podstawy prawnej ${ }^{38}$.

Wysokość miesięczną dodatku rektorskiego przedstawia tabela 3, zaś dodatku prorektorskiego tabela 4. Warto zwrócić uwagę, że ten ostatni został wprowadzony dopiero od 1 IX 1933 r. i uprzednio nie funkcjonował ${ }^{39}$.

${ }^{35}$ Należy jednak zastrzec, że przepisy uposażeniowe obowiązujące od 1 II $1934 \mathrm{r}$. posługiwały się równolegle i oddzielnie dwoma pojęciami: dodatku funkcyjnego i dodatku służbowego. Miały one w rzeczywistości podobny charakter, a różnica sprowadzała się przede wszystkim do tego, że o dodatku funkcyjnym mówiono w odniesieniu do wyższych kierowniczych funkcji państwowych, podczas gdy o dodatku służbowym jedynie w odniesieniu do niższych kierowniczych funkcji w sektorze państwowym. Charakter obu dodatków był jednak niemal identyczny.

${ }^{36}$ Dz. U. 1933, nr 102, poz. 781.

${ }^{37}$ Rozporzqdzenie Ministra Wyznań Religijnych i Oświecenia Publicznego z dnia 31 sierpnia 1933 r. wydane w porozumieniu z Ministrem Skarbu, ustalajace wysokość dodatkowych wynagrodzeń rektora, prorektorów, dziekanów i kierowników oddziałów i studiów w państwowych szkołach akademickich, Dz. U. 1933, nr 73, poz. 534.

${ }^{38}$ Dz. U. 1933 , nr 73, poz. 534; Dz. U. 1933, nr 102, poz. 781. W stosunku do stanu z sierpnia 1933 r. dodatki funkcyjne za kierowanie zakładem zostały nieznacznie zmniejszone: o 4,5 zł w przypadku zakładu dużego i 3 zł w odniesieniu do zakładu małego. J. Jastrzębski, Uposażenie profesora zwyczajnego..., s. 157-182.

${ }^{39}$ Dz. U. 1933, nr 73, poz. 534. 
Wcześniej bowiem prorektor pełnił swój urząd bezpłatnie, a prawo do dodatku rektorskiego miał tylko w przypadku pełnienia obowiazków rektorskich ${ }^{40}$. Zmiana wiązała się z Akademicką Reformą Jędrzejewiczowską z 1933 r. ${ }^{41}$, która nałożyła na prorektora większą ilość obowiąków ${ }^{42}$, niż to miało miejsce w okresie funkcjonowania pierwszej akademickiej ustawy ustrojowej z 1920 r., gdy obowiazki te pozostawały niewielkie i miały charakter głównie honorowy ${ }^{43}$.

Tabela 3. Dodatek rektorski - wysokość miesięczna w okresie od 1 II 1934 do 30 IX $1939 \mathrm{r}$.

\begin{tabular}{l|c}
\hline \multicolumn{1}{c|}{ Funkcja } & Kwota (zl) \\
\hline Rektor Uniwersytetu Jagiellońskiego & \\
\cline { 1 - 1 } Rektor Uniwersytetu Jana Kazimierza we Lwowie & \\
\hline Rektor Uniwersytetu Józefa Piłsudskiego w Warszawie & \\
\hline Rektor Uniwersytetu Poznańskiego & \multirow{2}{*}{500,00} \\
\hline Rektor Uniwersytetu Stefana Batorego w Wilnie & \multirow{2}{*}{400,00} \\
\hline Rektor Politechniki Lwowskiej & \\
\hline Rektor Politechniki Warszawskiej & \\
\hline Rektor Akademii Górniczej w Krakowie & \\
\hline Rektor Szkoły Głównej Gospodarstwa Wiejskiego w Warszawie & \multirow{2}{*}{300,00} \\
\hline Rektor Akademii Medycyny Weterynaryjnej we Lwowie & \\
\hline Rektor Akademii Sztuk Pięknych w Krakowie & \\
\hline Rektor Akademii Stomatologicznej w Warszawie & \\
\hline
\end{tabular}

Źródło: Opracowanie własne na podstawie: Dz. U. 1933, nr 29, poz. 247; Dz. U. 1933, nr 86, poz. 663; Dz. U. 1933, nr 102, poz. 781.

${ }^{40}$ J. Jastrzębski, Funkcja Prorektora $w$ państwowych szkołach akademickich II Rzeczypospolitej, „Przegląd Historyczno-Oświatowy” 2011, nr 1-2 (211-212), s. 31-43; tenże, Funkcja Rektora w państwowych szkołach akademickich II Rzeczypospolitej, „Przegląd Historyczno-Oświatowy” 2010, nr 1-2 (207-208), s. 63-82.

${ }^{41}$ Tenże, Reforma szkolnictwa akademickiego $z 1933$ roku. Zmiany $w$ organizacji uczelni, „Wschodni Rocznik Humanistyczny” 7, 2011, s. 255-272; tenże, Reforma Jędrzejewicza w państwowym szkolnictwie akademickim II Rzeczypospolitej. Wzmocnienie prerogatyw władz państwowych, „Zeszyty Naukowe Uniwersytetu Jagiellońskiego. Prace Historyczne" 2011, z. 138, s. 159-176.

${ }^{42}$ Ustawa z dnia 15 marca 1933 r. o szkołach akademickich, Dz. U. 1933, nr 29, poz. 247. Ogłoszona 29 kwietnia 1933 r. Weszła w życie 1 V 1933 r., a w pełnym zakresie 1 IX tegoż roku. Ujednolicona została raz Obwieszczeniem Ministra Wyznań Religijnych i Oświecenia Publicznego z dnia 8 listopada 1937 r. w sprawie ogłoszenia jednolitego tekstu ustawy z dnia 15 marca 1933 r. o szkołach akademickich, Dz. U. 1938, nr 1, poz. 6. Uchylona 30 X 1947 r. Dekretem z dnia 28 października 1947 r. o organizacji nauki i szkolnictwa wyższego, Dz. U. 1947, nr 66, poz. 415.

${ }^{43}$ Ustawa z dnia 13 lipca 1920 r. o szkołach akademickich, Dz. U. 1920, nr 72, poz. 494. Ogłoszona 10 VIII 1920 r. Weszła w życie 15 IX 1920 r. Uchylona 1 IX 1933 r. Ustawa z dnia 15 marca 1933 r. o szkołach akademickich, Dz. U. 1933, nr 29, poz. 247. 
Tabela 4. Dodatek prorektorski - wysokość miesięczna w okresie od 1 II 1934 do 30 IX 1939 r.

\begin{tabular}{l|c}
\hline \multicolumn{1}{c|}{ Funkcja } & Kwota (zt) \\
\hline Prorektor Uniwersytetu Jagiellońskiego & \\
\cline { 1 - 1 } Prorektor Uniwersytetu Jana Kazimierza we Lwowie & \multirow{2}{*}{300,00} \\
\hline Prorektor Uniwersytetu Józefa Piłsudskiego w Warszawie & \\
\hline Prorektor Uniwersytetu Poznańskiego & \\
\hline Prorektor Uniwersytetu Stefana Batorego w Wilnie & \\
\hline Prorektor Politechniki Lwowskiej & \multirow{2}{*}{250,00} \\
\hline Prorektor Politechniki Warszawskiej & \\
\hline Prorektor Akademii Górniczej w Krakowie & \multirow{2}{*}{200,00} \\
\hline Prorektor Akademii Medycyny Weterynaryjnej we Lwowie & \\
\hline Prorektor Akademii Sztuk Pięknych w Krakowie & \\
\hline Prorektor Akademii Sztuk Pięknych w Warszawie & \\
\hline Prorektor Akademii Stomatologicznej w Warszawie & \\
\hline
\end{tabular}

Źródło: Opracowanie własne na podstawie: Dz. U. 1933, nr 29, poz. 247; Dz. U. 1933, nr 86, poz. 663; Dz. U. 1933, nr 102, poz. 781.

Wysokość dodatku dziekańskiego w poszczególnych uczelniach akademickich $\mathrm{w}$ interesującym nas okresie przedstawia tabela 5, zaś pozostałe dodatki za kierownictwo oddziałem, studium z własnym statutem oraz zakładem obrazuje tabela $6^{44}$. Przy czym za zakład duży uważano taki, w którym liczba zapisanych studentów przekroczyła 100 osób, lub zakład doświadczalny o mniejszej liczbie studentów, ale w którym do prowadzenia zajęć niezbędne było uprzednie przygotowywanie przyrzadów i preparatów naukowych. Wszystkie zakłady niespełniające przynajmniej jednego z powyższych warunków były uważane za małe. Podziału zakładów na duże i małe dokonywał rektor danej szkoły akademickiej na rok akademicki, biorąc pod uwagę dane o frekwencji studentów w poszczególnych zakładach na dzień 15 listopada ${ }^{45}$. Rektor przyznawał kierownikowi zakładu stosowny dodatek funkcyjny na rok akademicki ${ }^{46}$.

${ }^{44}$ Dz. U. 1933, nr 102, poz. 781.

${ }^{45} \mathrm{Z}$ wyjątkiem okresu od 1 II do 1 IX 1934 r., na który rektor przyznawał dodatek według danych na dzień $1 \mathrm{~V} 1934 \mathrm{r}$.

${ }^{46}$ Rozporzadzenie Ministra Wyznań Religijnych i Oświecenia Publicznego $z$ dnia 21 listopada 1934 r. o podziale zakładów w państwowych szkołach akademickich na duże i małe, oraz o przyznawaniu dodatków służbowych za ich kierownictwo, Dz. Urz. Min. W.R.O.P. 1934, nr 9, poz. 142. Ogłoszone 15 XII 1934 r. Weszło w życie z moca wsteczną od 1 II $1934 \mathrm{r}$. 
Tabela 5. Dodatek dziekański - wysokość miesięczna w okresie od 1 II 1934 do 30 IX 1939 r.

\begin{tabular}{l|c}
\hline \multicolumn{1}{c|}{ Funkcja } & Kwota (zł) \\
\cline { 1 - 1 } Dziekan wydziału Uniwersytetu Jagiellońskiego & \\
\cline { 1 - 1 } Dziekan wydziału Uniwersytetu Jana Kazimierza we Lwowie & \multirow{2}{*}{250,00} \\
\cline { 1 - 1 } Dziekan wydziału Uniwersytetu Józefa Piłsudskiego w Warszawie & \\
\cline { 1 - 1 } Dziekan wydziału Uniwersytetu Poznańskiego & \\
\cline { 1 - 1 } Dziekan wydziału Uniwersytetu Stefana Batorego w Wilnie & \\
\cline { 1 - 1 } Dziekan wydziału Politechniki Lwowskiej & \multirow{2}{*}{200,00} \\
\cline { 1 - 1 } Dziekan wydziału Politechniki Warszawskiej & \\
\cline { 1 - 1 } Dziekan wydziału Akademii Górniczej w Krakowie & \\
\hline
\end{tabular}

Źródło: Opracowanie własne na podstawie: Dz. U. 1933, nr 29, poz. 247; Dz. U. 1933, nr 86, poz. 663; Dz. U. 1933, nr 102, poz. 781.

Tabela 6. Dodatek za kierownictwo oddziałów, studiów i zakładów akademickich - wysokość miesięczna w okresie od 1 II 1934 do 30 IX 1939 r.

\begin{tabular}{l|c}
\hline \multicolumn{1}{c|}{ Funkcja } & Kwota (z) \\
\hline Kierownik oddziału & 200,00 \\
\hline Kierownik studium z własnym statutem & 60,00 \\
\hline Kierownik zakładu dużego & 40,00 \\
\hline Kierownik zakładu małego & \\
\hline
\end{tabular}

Źródło: Opracowanie własne na podstawie: Dz. U. 1933, nr 86, poz. 663; Dz. U. 1933, nr 102, poz. 781.

\section{Zakończenie}

Zagadnienie uposażenia profesorów zwyczajnych w II Rzeczypospolitej zostało dotąd opracowane naukowo dla lat 1923-1939 (system punktowy i system kwotowy), a zatem wciąż oczekuje na analizę okres 1919-1923 (przede wszystkim system mnożnikowy). Autor prowadzi w tym ostatnim zakresie bardzo zaawansowane badania, które $\mathrm{w}$ niedługim czasie powinny zaowocować publikacja. Już jednak na tym etapie można dopatrzyć się dwóch wyraźnych trendów w regulacjach normatywnych odnoszacych się do interesujacych nas tu spraw dla całego okresu międzywojennego. Pierwszym było stałe upraszczanie systemu uposażeniowego od strony legislacyjnej i biurokratycznej. Drugim - wzrost stabilności uregulowań normatywnych, które początkowo były bardzo zmienne w wielu aspektach, $\mathrm{z}$ czasem jednak dopracowano się trwalszych rozwiązań. Oba trendy bezsprzecznie pozostaja w korelacji z ogólną sytuacja gospodarczą Polski. W okresie przyspie- 
szonej inflacji stosowano bardzo skomplikowane systemy wynagrodzeń, które w teorii powinny przynajmniej częściowo niwelować dynamiczne zmiany $\mathrm{w}$ poziomie cen. Próba poradzenia sobie z tym problemem w latach 1920-1923 za pomocą systemu mnożnikowego okazała się nieskuteczna. Dopiero kolejny system, punktowy, z lat 1923-1934, sprostał zadaniu, stanowiąc jeden $\mathrm{z}$ istotnych elementów stabilizacji waluty i finansów publicznych w ramach reformy Władysława Grabskiego. Zdławienie inflacji, a następnie deflacja związana z wielkim kryzysem gospodarczym pozwoliła na wprowadzenie bardzo prostego systemu kwotowego, który przy okazji pozwolił na oszczędności czasu pracowników administracyjnych, uwolnionych od nadmiaru buchalterii, oraz zwiększył przejrzystość uposażeń.

Jarosław Jastrzębski

Remuneration of a full professor in Polish state academic schools from 1 February 1934 to 30 September 1939

(Summary)

The aim of the article is to present the principles behind the system for remunerating full professors in Polish state academic schools in the years 193439 , and changes in the level of the remuneration in that period. The following remuneration systems were also compared: the quota system, established on 1 February 1934 and in force until the outbreak of World War II, and the preceding point scoring system in force in the years 1923-34.

The study is based on source materials such as an analysis of state legal acts dating from 1918-39. To begin with, particular stages of the transformation of the legislation governing remuneration in academic schools are discussed, and the position of the quota remuneration system that existed. It then presents the essence of the new remuneration system and particular components of the remuneration are classified into the base salary and supplementary remuneration; where the supplementary remuneration comprised: a local allowance and function-related allowance. These amounts are compared to the previous status, in an attempt to find a common denominator for data from different periods and to prepare the most reliable comparisons.

The amount of a professor's remuneration, established in 1934, remained stable until the end of the interwar period. Until 1939 no changes were made to the amount of a full professor's various remuneration components. The rules for paying them did not change to any great extent. This was associated with the general economic situation in Poland, as well as being related to the successful implementation of new legal regulations.

Key w ord s: history of university-level studies, ordinary professor, economic history, remuneration of academic teachers' in the Second Polish Republic 